\title{
COMPARISON OF THRIPS SENSITIVITY OF THREE COMMERCIAL CHRYSANTHEMUM CULTIVARS
}

\author{
Tímea Kelemen ${ }^{1}$, János Ágoston ${ }^{1 *}$ \\ 1 John von Neumann University, Faulty of Horticulture and Rural Development, Department of Agriculture. \\ 6000 Kecskemét, Mészöly Gyula tér 1-3. Hungary \\ https://doi.org/10.47833/2020.3.AGR.006
}

\author{
Keywords: \\ Dendranthema $\times$ grandiflorum \\ Frankliniella occidentalis \\ Thrips tabaci \\ Hungary \\ Tomato spotted wilt \\ orthotospovirus
}

Article history:

Received 12 Nov 2020

Revised 20 Nov 2020

Accepted 25 Nov 2020

\begin{abstract}
Western flower thrips (Frankliniella occidentalis) and onion thrips (Thrips tabaci) are very important pests of vegetables and ornamentals grown under protected conditions. Both are vectors of several Orthotospovirus species. We wanted to know if these insects have a host preference and a gradation period, so we contacted a cut chrysanthemum grower in south Bács-Kiskun county if he would allow us to follow up the occurrence of these thrips species in his nursery. We carried out our trial from 2015 to 2019 on 3 cultivars. These cultivars are popular cut flowers in Hungary and are grown successfully by many growers. Based on our results we were able to answer both questions.
\end{abstract}

\section{Introduction}

Chrysanthemum (Dendranthema $\times$ grandiflorum) was the $6^{\text {th }}$ most popular cut flower in the world in 2017. The world's cut chrysanthemum production was 9,7 million stems in that year, and $84 \%$ of them were grown in the Netherlands. In 2017 Hungary sold 187000 stems on external markets [15], so chrysanthemum production is an important product of the Hungarian Floricultural market.

In Hungary the most important pests of chrysanthemum are thrips (Thripidae), spider mites (Tetranychus urticae), cotton bollworm (Helicoverpa armigera), and flower bugs (Anthocoridae) [3, 12].

From thrips the most important pest is the invasive western flower thrips (Frankliniella occidentalis), which causes serious problems for growers. Its Hungarian native counterpart onion thrips' (Thrips tabaci) damage is only slight behind. Both species are sucking on the flowers and foliage causing deformations, color change decreasing the value and shelf life of the product. Their indirect damage manifests as being the vectors for several Orthotospovirus species. Tomato spotted wilt orthotospovirus is one of the most important viral diseases of chrysanthemum, it can cause $100 \%$ crop loss [19].

\subsection{Western flower thrips (Frankliniella occidentalis)}

Western flower thrips is native in the western region of the USA, but since the 1970s it has spread worldwide - except Greenland and Antarctica (Figure 1).

Corresponding author. Tel.: +36 76 517-726

E-mail address: agoston.janos@kvk.uni-neumann.hu 


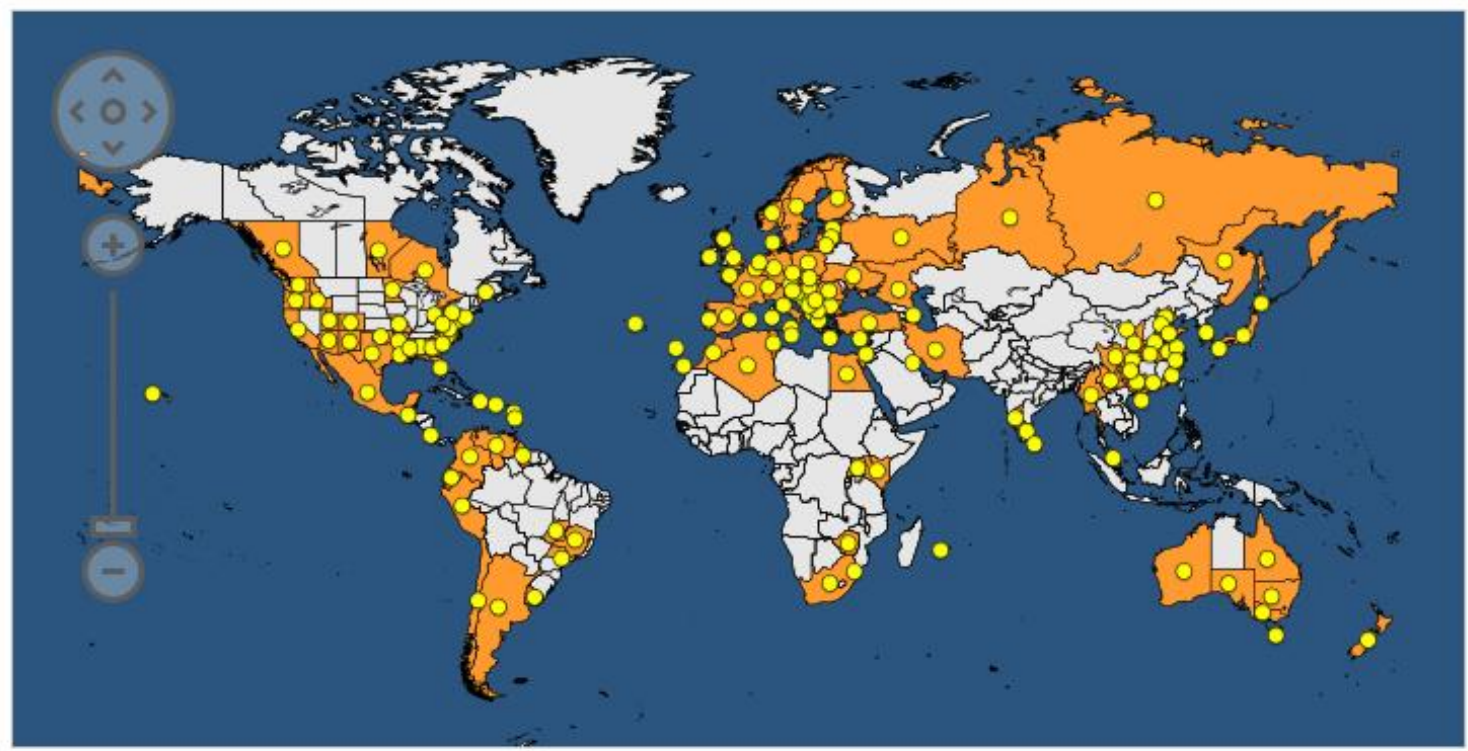

Figure 1. Worldwide distribution of Frankliniella occidentalis [7]

(Source: https://gd.eppo.int/taxon/FRANOC/distribution)

Nobody knows how exactly it had spread throughout Europe. Possibly their ability to become quickly resistant to insecticides and the ever-increasing trade of cut flowers and potted plants benefited its spread. Researchers assume it has appeared on the continent few years before it was identified as a pest in a Dutch rose nursery in 1984. By 1986 it spread widely, mostly with the help of infected cut chrysanthemums. It was first reported from Hungary in 1989 in Budapest on floristbought gerbera [18]. First populations were successfully eradicated, but new waves of the pest arrived - possibly with imported cut flowers - and stayed [8, 9, 13, 27]. After its introduction it became an important pest of the heat demanding forced crops. According to the survey of the Office of Agricultural Administration's county Plant and Soil Directorate's survey this pest was present on $87 \%$ of the surveyed sites [10, 28].

Frankliniella occidentalis is a polyphagous pest. On the Northern and Middle parts of Europe it is mainly a glasshouse pest, but on the South it harms open field crops such as vegetables, ornamentals and even fruit trees [5, 20,21]. Being the vector of several Orthothospovirus species further increases its significance, mainly being the main vector of Tomato spotted wilt orthotospovirus (TSWV) [4, 10, 14, 24].

\subsection{Onion thrips (Thrips tabaci)}

It is a cosmopolitan species with nearly worldwide distribution (Figure 2). It can be found wherever onion is grown, on the tropics, on warm and colt temperate regions. It is native and widespread in Hungary, commonly occurring in great numbers [17]. 


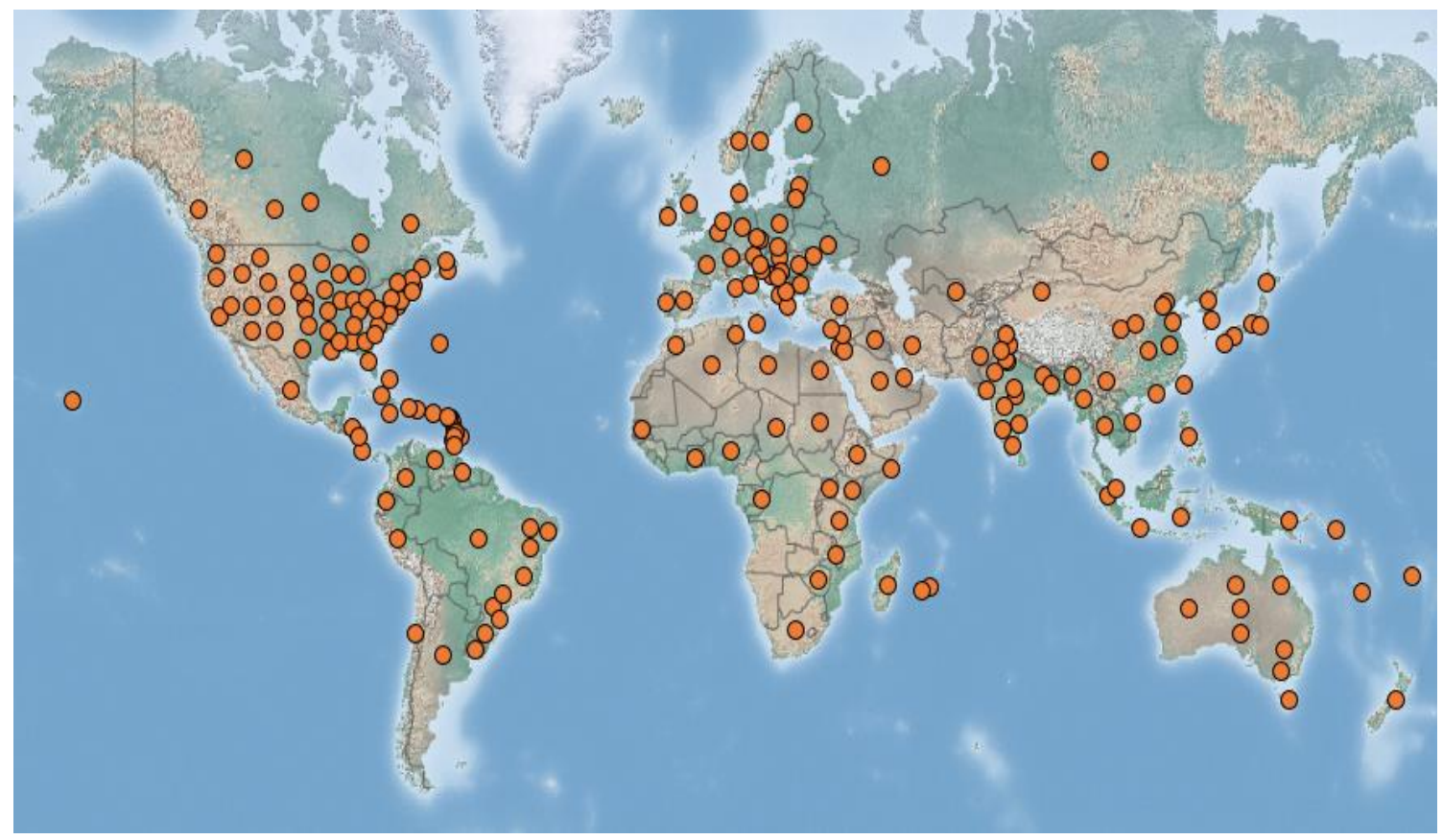

Figure 2. Distribution of Thrips tabaci

(Source: https://www.cabi.org/isc/datasheet/53746\#toDistributionMaps)

Polyphagous species, which have been reported from several hundreds of host plants. Not specialized on flowers or foliage, it is present on all parts of the plants. Also the vector of Tomato spotted wilt orthotospovirus [16].

\subsection{Life cycle}

Both species can reproduce both sexual and asexual ways. Females lay eggs one by one in soft plant tissues with their serrated ovipositors. Eggs hatch to larvae and go through 2 larval stages, which feed on the plant. $L_{2}$ usually moves down to the soil and molts into pre-pupa, which does not feed and only moves when disturbed, then molt to pupa, which also stays in the soil and moves only when disturbed. Adults emerge from the pupa and move back to the plant to feed, mate and to fly to other host plants [5, 21].

\subsection{Signalization}

Both species are attracted to color sticky traps. In Europe blue and lilac sticky traps are used, while in America yellow traps are more common [22]. Western flower thrips responds well to white, blue and yellow colors, with low reflection in ultraviolet spectrum [1]. Sticky traps are useful for scouting for the pest. Both species tend to migrate to sheltered places (glasshouses, poly tunnels, window sills) when air pressure drops before rain. This helps the insects to survive adverse conditions and act as a reservoir.

With our research we would like to answer the following questions:

- Does thrips have a cultivar preference?

- Does thrips occur continuously throughout the growing season at a stable number or they gradate?

\section{Methods}

Our experiments were carried out in south Bács-Kiskun county from 2015 to 2019. Multiheaded chrysanthemums were grown in 6 heated poly tunnels, received professional and reasonable crop care (fertigation, crop protection) from the grower. Flowering of the plants were 
timed from early February to late November, with a small interruption of winter rest, when soil disinfection and tunnel sanitation took place. We only tested 3 cultivars.

We were advised to anonymize the cultivars and not to use the cultivar/trade name as one might interpret our research as an attempt to damage the good reputation of these cultivars and the breeder, which could not be further from our intentions.

\subsection{Assessments}

Assessments were carried out according to crop specific EPPO protocols [6], but we did not included repetitions as our earlier research (2014-2015) showed no significant difference between repetitions. 25 open inflorescences were picked at each date of assessment from each cultivar ready to be picked.

Because of the lengthy procedure of preparing thrips for microscopic identification, and the total number of thrips collected (>2000) we did not identified the specimens to species level.

\subsection{Sampling method}

Inflorescences were directly picked to plastic bags, which were tightly sealed. Before processing, bagged samples were chilled at $4^{\circ} \mathrm{C}$ for at least 2 hours. Chilling made the animals numb, so they would not fly away when opening the bags.

\subsection{Processing of samples}

Because of the vast number of collected inflorescences (>1000) we did not dissected them, nor did we knock them on white paper sheets. Instead we used the ethanol extraction method which is 2-3 times more efficient than knocking the flowers [11], and in effectiveness comparable to inflorescence dissection, but 5-6 times faster [2, 11, 25].

We made some improvements on this method. After chilling the samples, they were directly put in to $70 \%(\mathrm{v} / \mathrm{v})$ ethanol solution for $10-15$ minute with occasional agitation. The volume of the solution was 2-3 times of the volume of the sample, which killed the thrips. Agitation was necessary to enable the dead thrips to sink to the bottom of the solution. Plant material was cautiously removed from the solution avoiding the mixing of the solution. The solution then was stirred and filtered through 2 ply paper napkins or 2 ply paper towels. The paper allowed the ethanol to pass through but thrips were stuck to them. The solution's container was then washed with $70 \%$ ethanol twice to remove all specimens. The paper could be stored in ethanol solution for later assessment or specimens could be counted after 10-15 minute air drying at room temperature under a stereo microscope. The flow through was collected and could be re-used as long as the ethanol concentration did not drop below $50 \%(\mathrm{v} / \mathrm{v})$. This concentration is needed to promptly kill the animals. Discoloration of the solution readily occurs because ethanol extracts several plant pigments but this had no effect on the extraction process. Only thrips resembling in size and color of onion thrips or western flower thrips were counted the rest were ignored.

\subsection{Relative thrips density}

For better interpretability and comparability of data we provide not only the number of individuals found in the inflorescences, but we express their number in unit of flower area and flower volume [23].

\subsubsection{Inflorescence area measurement}

In the beginning of the trial we scanned inflorescences with a ruler, then the area of the inflorescences were determined with FiJi program [26]. As sample number grew and because our results did not differ significantly $(<5 \%)$ from the calculated area based on flower diameters published in catalogues we decided to use the areas calculated from flower diameters from catalogues.

\subsubsection{Inflorescence volume measurement}

Inflorescences were submersed in a graduated cylinder filled with an exact amount of tap water. Total volume was read at the meniscus. The inflorescence volumes were calculated by subtracting the known volume of water from the total volume. 


\section{Results}

\subsection{General damage}

Thrips can cause several types of damage. If the population is big enough or there is not enough flowers open both western flower thrips and onion thrips can suck on the foliage causing leaf scabs (Figure 3).

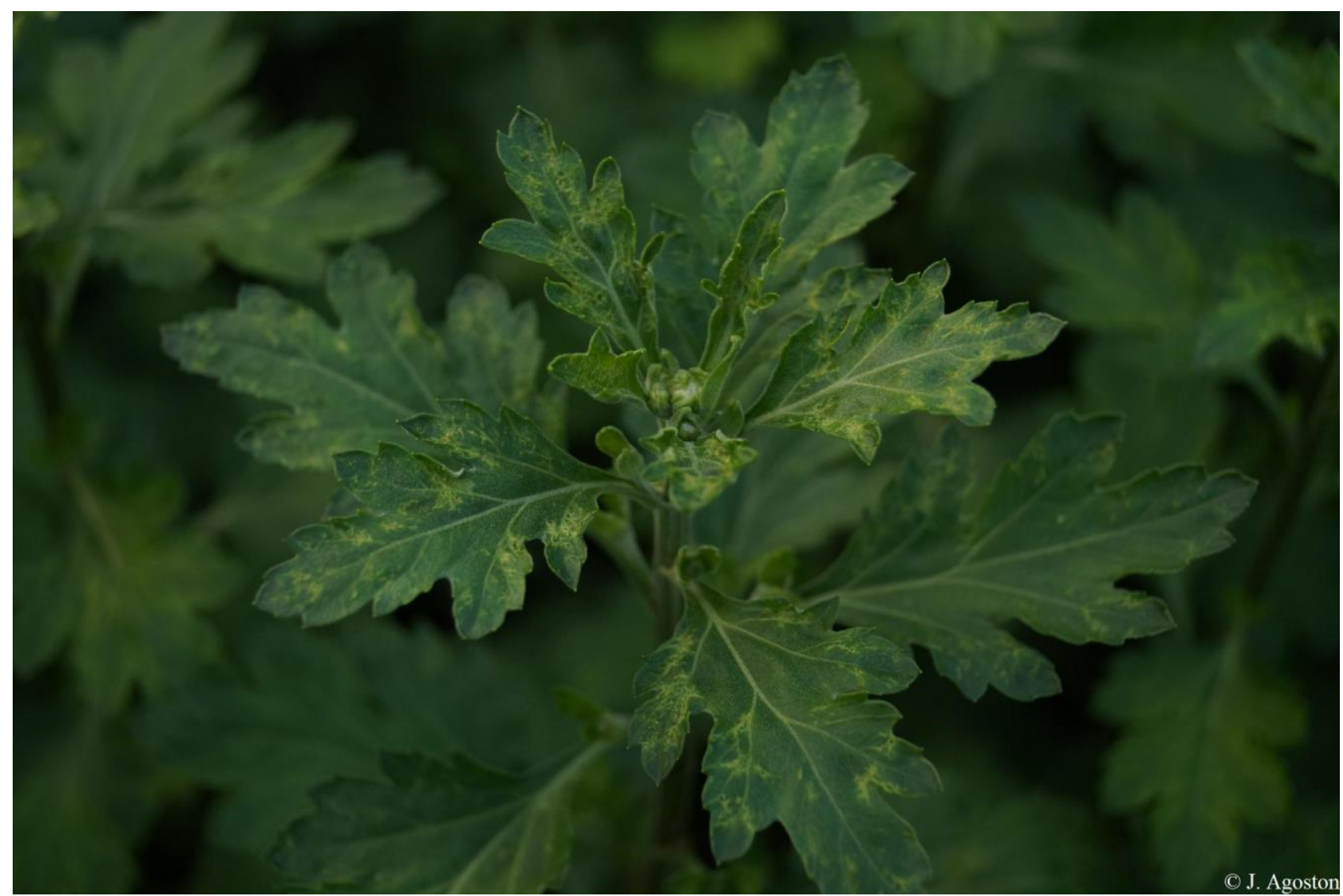

Figure 3. Leaf scabs caused by thrips sucking on young leaves.

Their indirect damage is spreading viruses. Tomato spotted wilt is a serious problem in chrysanthemum production. Infected plants cannot be cured and must be destroyed immediately before the virus spreads to neighboring plants (Figure 4). 


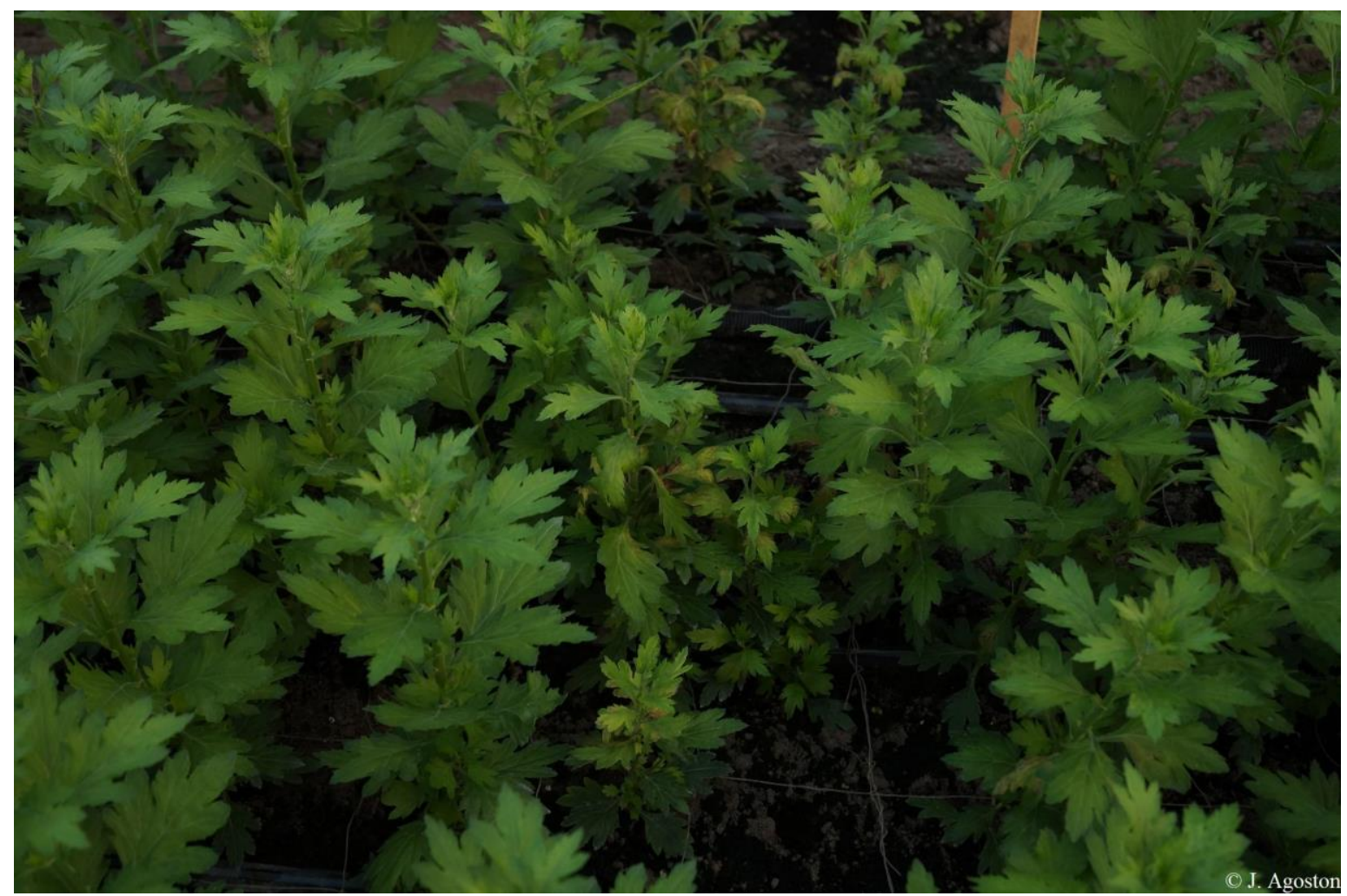

Figure 4. TSVW infection on cut chrysanthemum (front and center, middle).

Symptoms rage from concentric leaf spots, leaf and flower stalk distortion to wilting, stunting, shoot necrosis, abortion of buds to total destruction of the plant.

Occasionally larvae can be spotted with bare eyes on the underside of the leaves (Figure 5).

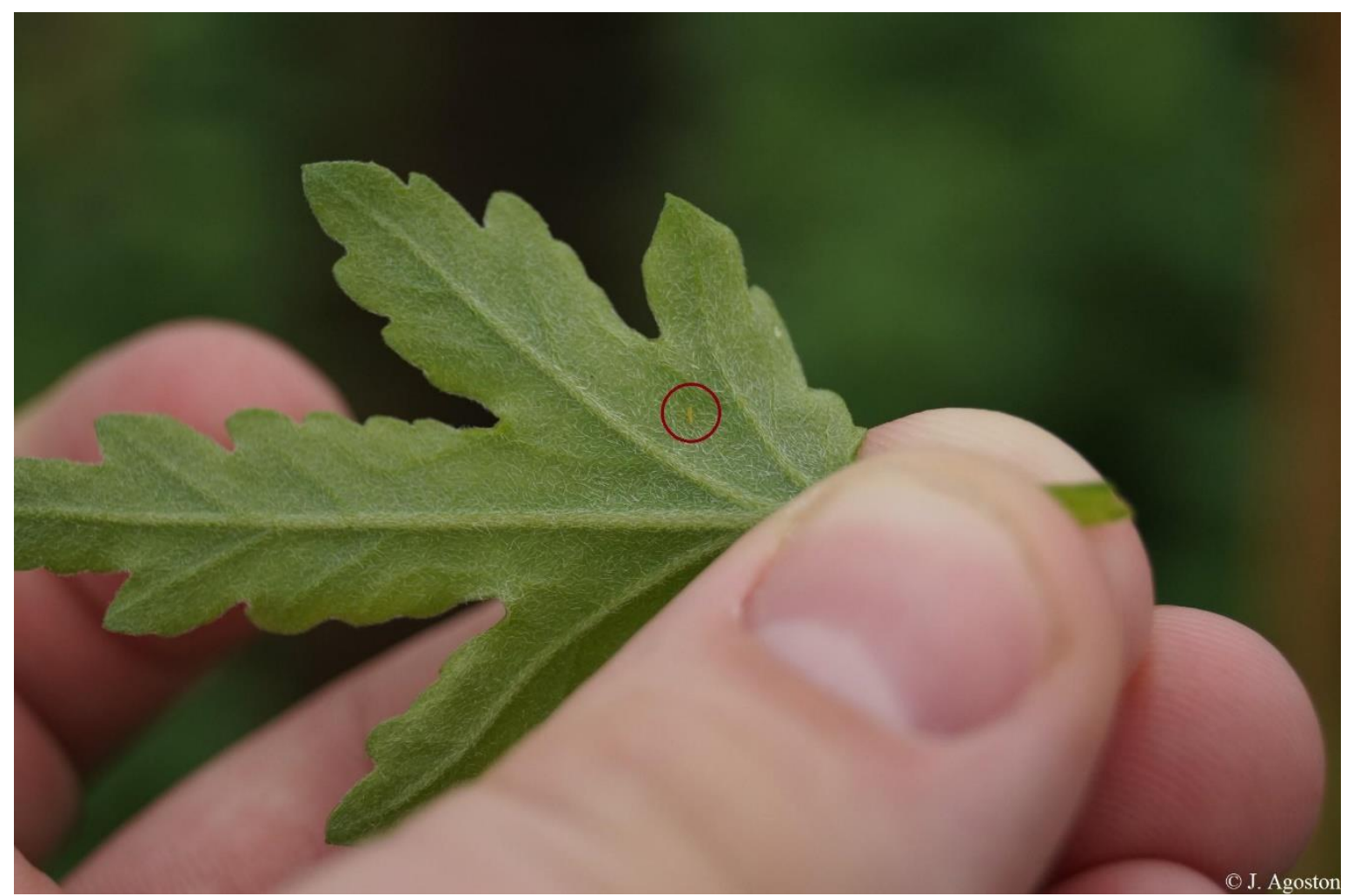

Figure 5. $L_{2}$ larvae feeding on the underside of a leaf. Red circle indicates the larvae. 


\subsection{Damage by cultivars}

The number of thrips individuals counted in cultivar No. 1 are shown in Figure 6.

Number of thrips in cultivar No. 1 per 25 inflorescence

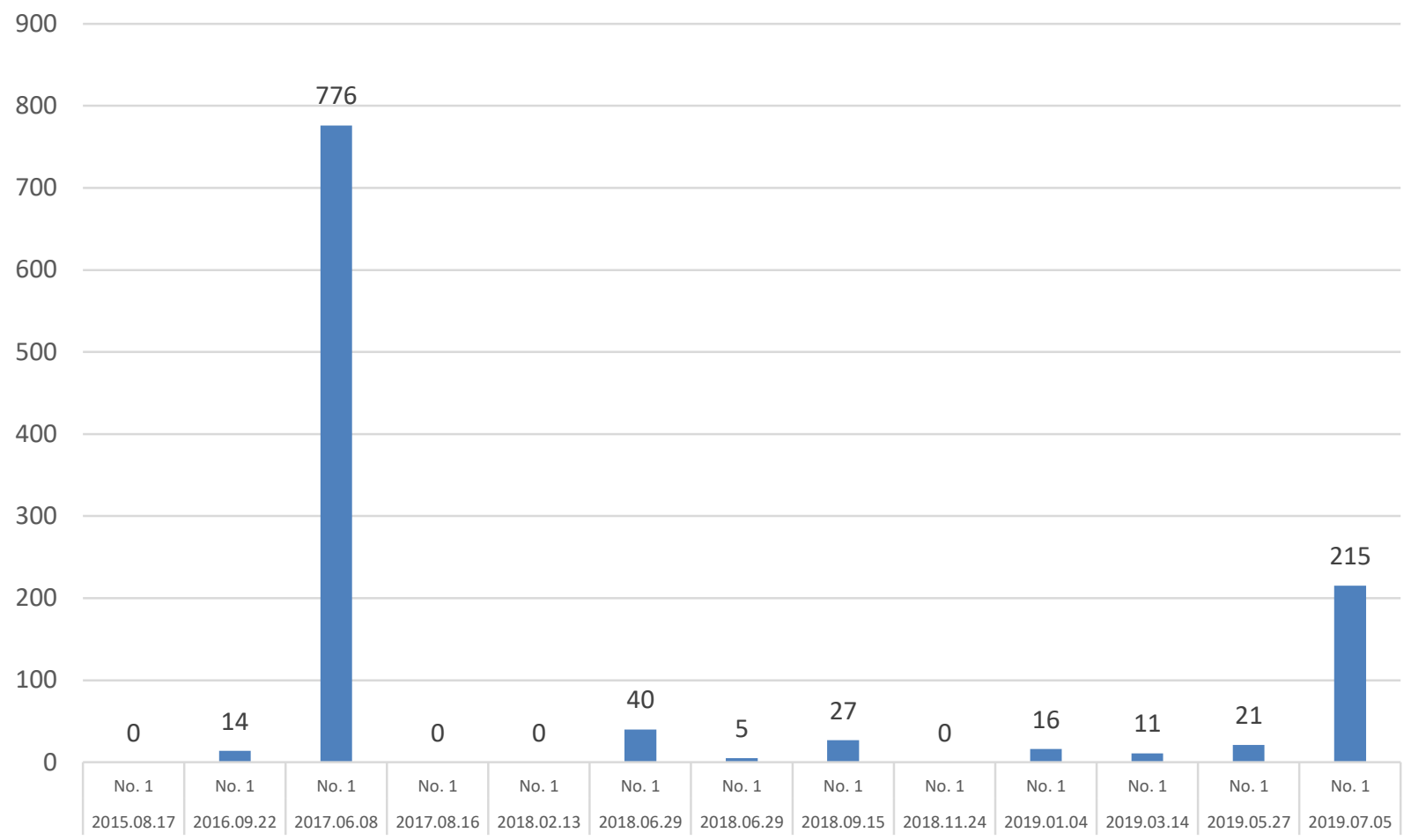

Figure 6. Number of thrips in cultivar No. 1 per assession date

We can see that thrips numbers are high in summer months. At $8^{\text {th }}$ of June 2017 an exceptionally high number of thrips have been observed, 776 individuals were extracted from 25 inflorescence. This caused serious losses in the plantation forcing the grower to discard his entire plantation of this cultivar. 


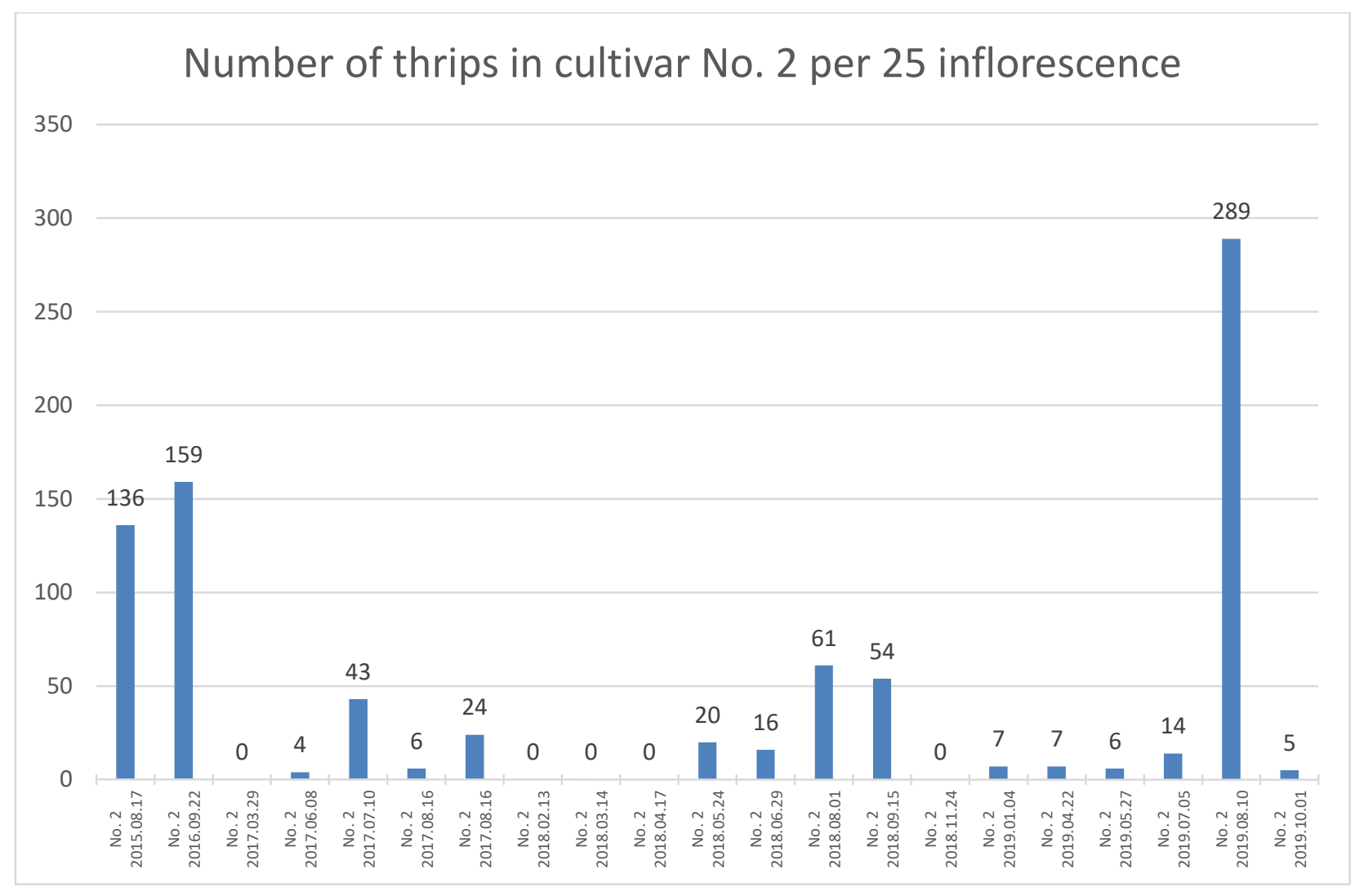

Figure 7. Number of thrips in cultivar No. 2 per assession date

In the case of cultivar No. 2 thrips were more prevalent in the summer months. Very high numbers of thrips were observed at $17^{\text {th }}$ of August 2015, $22^{\text {nd }}$ of September 2016 and $10^{\text {th }}$ of August 2019. This cultivar seems to be more susceptible to TSWV than the other two tested cultivars according to the grower. 


\section{Number of thrips in cultivar No. 3 per 25 inflorescence}

80

70

67

60

62

50

40

30

20

10

0

$0 \quad 0$

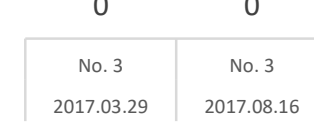

3

No. 3

2017.09.20
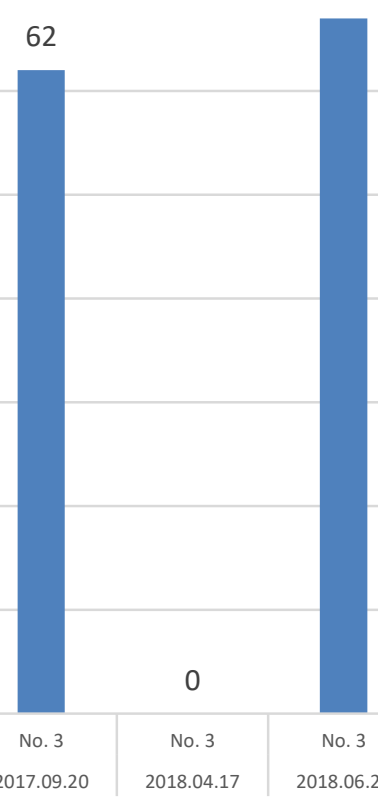

28

Figure 8. Number of thrips in cultivar No. 3 per assession date

In the case of cultivar No. 3 thrips were most prevalent in June and September. High number of individuals were extracted on $20^{\text {th }}$ of September 2017 and $29^{\text {th }}$ of June 2018.

\subsection{Relative thrips density by area and volume}

Summarizing our results with number of thrips per unit of inflorescence area and volume are presented in Table 1, where we present the data in descending order by the total number of thrips extracted from inflorescences.

Table 1. Summary of data compiled from our results

\begin{tabular}{|c|c|c|c|c|c|c|}
\hline \multirow[b]{2}{*}{ Date } & \multirow[b]{2}{*}{ Cultivar } & \multicolumn{3}{|c|}{ Total } & \multirow[b]{2}{*}{ Thrips/cm ${ }^{2}$} & \multirow[b]{2}{*}{ Thrips $/ \mathrm{cm}^{3}$} \\
\hline & & $\begin{array}{c}\text { number } \\
\text { of } \\
\text { thrips }\end{array}$ & $\begin{array}{c}\text { area of } \\
\text { inflorescences } \\
\left(\mathrm{cm}^{2}\right)\end{array}$ & $\begin{array}{c}\text { volume of } \\
\text { inflorescences } \\
\left(\mathrm{cm}^{3}\right)\end{array}$ & & \\
\hline 2017.06 .08 & No. 1 & 776 & 3848,451001 & 284 & 0,2016396 & 2,7323944 \\
\hline 2019.08.10 & No. 2 & 289 & 3848,451001 & 286 & 0,0750951 & 1,0104895 \\
\hline 2019.07.05 & No. 1 & 215 & 3848,451001 & 284 & 0,0558666 & 0,7570423 \\
\hline 2016.09.22 & No. 2 & 159 & 3848,451001 & 286 & 0,0413153 & 0,5559441 \\
\hline 2015.08 .17 & No. 2 & 136 & 3848,451001 & 286 & 0,0353389 & 0,4755245 \\
\hline 2018.06.29 & No. 3 & 67 & 5026,548246 & 287 & 0,0133292 & 0,2334495 \\
\hline 2017.09.20 & No. 3 & 62 & 5026,548246 & 287 & 0,0123345 & 0,2160279 \\
\hline 2018.08 .01 & No. 2 & 61 & 3848,451001 & 286 & 0,0158505 & 0,2132867 \\
\hline 2018.09.15 & No. 2 & 54 & 3848,451001 & 286 & 0,0140316 & 0,1888112 \\
\hline 2017.07.10 & No. 2 & 43 & 3848,451001 & 286 & 0,0111733 & 0,1503497 \\
\hline 2018.06.29 & No. 1 & 40 & 3848,451001 & 284 & 0,0103938 & 0,1408451 \\
\hline
\end{tabular}




\begin{tabular}{|c|c|c|c|c|c|c|}
\hline 2019.01 .04 & No. 3 & 28 & 5026,548246 & 287 & 0,0055704 & 0,097561 \\
\hline 2018.09 .15 & No. 1 & 27 & 3848,451001 & 284 & 0,0070158 & 0,0950704 \\
\hline 2017.08.16 & No. 2 & 24 & 3848,451001 & 286 & 0,0062363 & 0,0839161 \\
\hline 2019.05 .27 & No. 1 & 21 & 3848,451001 & 284 & 0,0054567 & 0,0739437 \\
\hline 2018.05 .24 & No. 2 & 20 & 3848,451001 & 286 & 0,0051969 & 0,0699301 \\
\hline 2018.06 .29 & No. 2 & 16 & 3848,451001 & 286 & 0,0041575 & 0,0559441 \\
\hline 2019.01 .04 & No. 1 & 16 & 3848,451001 & 284 & 0,0041575 & 0,056338 \\
\hline 2019.08 .10 & No. 3 & 16 & 5026,548246 & 287 & 0,0031831 & 0,0557491 \\
\hline 2016.09 .22 & No. 1 & 14 & 3848,451001 & 284 & 0,0036378 & 0,0492958 \\
\hline 2019.07 .05 & No. 2 & 14 & 3848,451001 & 286 & 0,0036378 & 0,048951 \\
\hline 2019.03 .14 & No. 1 & 11 & 3848,451001 & 284 & 0,0028583 & 0,0387324 \\
\hline 2019.01 .04 & No. 2 & 7 & 3848,451001 & 286 & 0,0018189 & 0,0244755 \\
\hline 2019.04 .22 & No. 2 & 7 & 3848,451001 & 286 & 0,0018189 & 0,0244755 \\
\hline 2017.08 .16 & No. 2 & 6 & 3848,451001 & 286 & 0,0015591 & 0,020979 \\
\hline 2018.09 .15 & No. 3 & 6 & 5026,548246 & 287 & 0,0011937 & 0,0209059 \\
\hline 2019.05 .27 & No. 2 & 6 & 3848,451001 & 286 & 0,0015591 & 0,020979 \\
\hline 2018.06 .29 & No. 1 & 5 & 3848,451001 & 284 & 0,0012992 & 0,0176056 \\
\hline 2019.10.01 & No. 2 & 5 & 11309,73355 & 286 & 0,0004421 & 0,0174825 \\
\hline 2017.06 .08 & No. 2 & 4 & 3848,451001 & 286 & 0,0010394 & 0,013986 \\
\hline 2015.08 .17 & No. 1 & 0 & 3848,451001 & 284 & 0 & 0 \\
\hline 2017.03 .29 & No. 2 & 0 & 3848,451001 & 286 & 0 & 0 \\
\hline 2017.03 .29 & No. 3 & 0 & 5026,548246 & 287 & 0 & 0 \\
\hline 2017.08.16 & No. 1 & 0 & 3848,451001 & 284 & 0 & 0 \\
\hline 2017.08.16 & No. 3 & 0 & 5026,548246 & 287 & 0 & 0 \\
\hline 2018.02 .13 & No. 1 & 0 & 3848,451001 & 284 & 0 & 0 \\
\hline 2018.02.13 & No. 2 & 0 & 3848,451001 & 286 & 0 & 0 \\
\hline 2018.03.14 & No. 2 & 0 & 3848,451001 & 286 & 0 & 0 \\
\hline 2018.04 .17 & No. 2 & 0 & 3848,451001 & 286 & 0 & 0 \\
\hline 2018.04 .17 & No. 3 & 0 & 5026,548246 & 287 & 0 & 0 \\
\hline 2018.08 .01 & No. 3 & 0 & 5026,548246 & 287 & 0 & 0 \\
\hline 2018.11 .24 & No. 1 & 0 & 3848,451001 & 284 & 0 & 0 \\
\hline 2018.11 .24 & No. 2 & 0 & 3848,451001 & 286 & 0 & 0 \\
\hline 2018.11 .24 & No. 3 & 0 & 5026,548246 & 287 & 0 & 0 \\
\hline
\end{tabular}

Our grower indicated, he considers the trips population medium when there is 1 thrips in 2 inflorescences. This is the threshold he is applying chemicals.

\section{Discussion}

According to our results from the cultivars we have tested No. 2 was the most preferred host by western flower thrips and onion thrips. Cultivar No. 1 had medium pest occurrence, while cultivar No. 3 was least preferred by them. This is a valuable information for growers as they have to pay more attention on scouting and timing of the spraying for more susceptible cultivars if they want to maintain a healthy and marketable product. 
Regarding the seasonality of thrips occurrence depending on the outside weather conditions they appear in April or May in the tunnels. Gradation should be expected in July and August. As the outside temperature decreases the population in the tunnels also decrease steadily in September and October. By the end of October or early November the catch can reduce below detection threshold.

\section{Conclusions}

The tested cultivars are widely grown in Europe and in Hungary. They are all good cultivars worthy of growing, but under Hungarian conditions some are more susceptible to thrips damage than others.

Based on our results we believe that thrips is not able to overwinter in the tunnels at this particular grower, because of lack of heating and the soil and tunnel sanitation treatments. Instead they migrate in from neighboring fields in spring. Settlement of the thrips population is aided by flowering weeds in the neighborhood, or goods returning from the market, where they might become infected from other grower's product, or from cultivars and annual bedding plants not grown by the grower but bought to broaden his assortment.

Incoming propagation material seems to be free from all life stages of thrips, as we only see the first individuals from April onward, when thrips is already present outdoors.

Because of the high pressure of inward migrating adults from nearby fields and meadows in the summer months the crop cannot be protected well from the damage, even when the grower makes all the efforts.

In autumn as temperature decreases the outside population starts to decrease too, inward migration gradually decreases, simultaneously the population inside the tunnels drop, and soon reduces below the detection threshold.

Biological crop protection is not a viable option, as temperature often rises over $40^{\circ} \mathrm{C}$ in the summer heat. While temperatures are very high, relative humidity decreases to $30-40 \%$ even with regular misting and continuous irrigation. These conditions are too harsh for predatory mites and capsid bugs.

Based on the growers' indication we propose 0,003 thrips per $\mathrm{cm}^{2}$ and 0,04 thrips per $\mathrm{cm}^{3}$ as an economic threshold in chrysanthemum cultivars, when application of insecticides is necessary to prevent economic loss.

\section{Data availability statement} request.

All raw data are available for viewing at the office of the corresponding author upon reasonable

\section{Acknowledgment}

This research is supported by EFOP-3.6.1-16-2016-00006 "The development and enhancement of the research potential at John von Neumann University" project. The Project is supported by the Hungarian Government and co-financed by the European Social Fund.

\section{References}

[1] Antignus Y. (2000) Manipulation of wavelength-dependent behaviour of insects: an IPM tool to impede insects and restrict epidemics of insect-borne viruses. Virus Research 71:213-220. https://doi.org/10.1016/S01681702(00)00199-4

[2] Arevalo H. A., Liburd O. E. (2007) Horizontal and vertical distribution of flower thrips in southern highbush and rabbiteye blueberry plantings, with notes on a new sampling method for thrips inside blueberry flowers. Journal of Economic Entomology 100:1622-1632. https://doi.org/10.1093/jee/100.5.1622

[3] Bálint J., Bognár S., Farkas K., et al. (1978) Kertészeti növényvédelem. Mezőgazdasági Kiadó, Budapest. ISBN: 963-230-380-6.

[4] Batuman O., Campbell A. J., Ullman D. E., Gilbertson R. L., McRoberts N., Coop L. (2015) Using a degree day insect development model to guide strategic management of western flower thrips and Tomato spotted wilt virus (family Bunyaviridae, genus Tospovirus) on processing tomato in the central valley of California. Acta Hortic 309-314. https://doi.org/10.17660/ActaHortic.2015.1069.44 
[5] van der Ent S., Knapp M., Klapwijk J., Moerman E., van Schelt J., de Weert S., Dik A., Schulthess F. (2017) Knowing and recognizing: the biology of pests, diseases and their natural solutions. Koppert Biological Systems, Berkel en Rodenrijs. ISBN: 978-90-827567-0-8.

[6] EPPO (2009) Efficacy evaluation of insecticides - Thrips on glasshouse crops. 3.

[7] EPPO (2020) EPPO Global Database (available online) https://gd.eppo.int.

[8] EPPO Reporting Service (1990) Frankliniella occidentalis on glasshouse and outdoor crops in Hungary. 1.

[9] EPPO Reporting Service (1991) Reinfestation of Frankliniella occidentalis in Hungary. 1.

[10] EPPO Reporting Service (2007) Survey on glasshouse thrips and tospoviruses in Hungary. 1.

[11] Finn E. (2003) Developing integrated pest management (IPM) techniques for managing key insect pests of blueberries in the southeastern united states. MSc, University of Florida

[12] Glits M., Horváth J., Kuroli G., Petróczi I. (eds) (1997) Növényvédelem. Mezőgazda Kiadó, Budapest. ISBN: 978-963-286-042-8.

[13] Hatala-Zsellér I. (1992) Situation of glasshouse pests in Hungary. EPPO Bulletin 22:411-415. https://doi.org/10.1111/j.1365-2338.1992.tb00519.x

[14] Hatala-Zsellér I., Kiss E. F. (1999) Control of Frankliniella occidentalis and TSWV in capsicum crops in Hungary. EPPO Bulletin 29:63-67. https://doi.org/10.1111/j.1365-2338.1999.tb00795.x

[15] International Association of Horticultural Producers (AIPH) (2018) International statistics: flowers and plants 2018. International Association of Horticultural Producers (AIPH)., Hannover. ISBN: 978-1-916480-70-4.

[16] Jenser G. (1995) A tripszek szerepe a paradicsom bronzfoltosság vírus terjedésében. Növényvédelem 31:541545.

[17] Jenser G. (1988) Rend: Tripszek - Thysanoptera. In: Jermy T, Balázs K (eds) A Növényvédelmi állattan kézikönyve 1. Akadémiai Kiadó, Budapest. pp. 283-305. ISBN: 978-963-05-4707-4.

[18] Jenser G., Tusnádi Cs. K. (1989) A nyugati virágtripsz (Frankliniella occidentalis Pergande) megjelenése Magyarországon. Növényvédelem 25:389-393.

[19] Kirk W. D. J. (2002) The pest and vector from the West: Frankliniella occidentalis. In: Marullo R, Mound LA, Australian National Insect Collection, Universita degli studi mediterranea di Reggio Calabria Facolta di Agraria Dipartimento di Agrochimica ed Agrobiologia (eds) Thrips and Tospoviruses: Proceedings of the 7th International Symposium on Thysanoptera. Canberra: Australian National Insect Collection CSIRO, Calabria. pp. 33-42. ISBN: 0-9750206-0-9.

[20] Kirk W. D. J., Terry L. I. (2003) The spread of the western flower thrips Frankliniella occidentalis (Pergande). Agric Forest Ent 5:301-310. https://doi.org/10.1046/j.1461-9563.2003.00192.x

[21] Malais M. H., Ravensberg W. J. (2003) Knowing and recognizing: the biology of glasshouse pests and their natural enemies. Koppert B.V, Berkel en Rodenrijs. ISBN: 978-90-5439-126-5.

[22] MTA ATK Növényvédelmi Intézet (2012) Nyugati virágtripsz - Frankliniella occidentalis Pergande.

[23] Papadaki M., Harizanova V., Bournazakis A. (2008) Influence of host plant on the population density of Frankliniella occidentalis Pergande (Thysanoptera: Thripidae) on different vegetable cultures in greenhouses. Bulg J Agric Sci 14:454-459.

[24] Reitz S. R., Gao Y., Kirk W. D. J., Hoddle M. S., Leiss K. A., Funderburk J. E. (2020) Invasion biology, ecology, and management of western flower thrips. Annu Rev Entomol 65:17-37. https://doi.org/10.1146/annurev-ento011019-024947

[25] Rhainds M., Cloutier C., Shipp L., Boudreault S., Daigle G., Brodeur J. (2007) Temperature-mediated relationship between western flower thrips (Thysanoptera: Thripidae) and Chrysanthemum. Environmental Entomology 36:475-483. https://doi.org/10.1093/ee/36.2.475

[26] Schindelin J., Arganda-Carreras I., Frise E., et al. (2012) Fiji: an open-source platform for biological-image analysis. Nat Methods 9:676-682. https://doi.org/10.1038/nmeth.2019

[27] Szabó P., Ceglarska-Hódi E. (1992) Western flower thrips (Frankliniella occidentalis) - occurrence and possibilities for its control in Hungary. EPPO Bulletin 22:377-382. https://doi.org/10.1111/j.13652338.1992.tb00514.x

[28] Vasziné Kovács C., Kiss F., Lucza Z. (2006) Frankliniella occidentalis Pergande és Thrips palmi Karny elterjedésének felderítése, összekapcsolva a Tospovirusok eltejedésének felülvizsgálatával Magyarországon (2002-2004). Növényvédelem 42:365-370. 